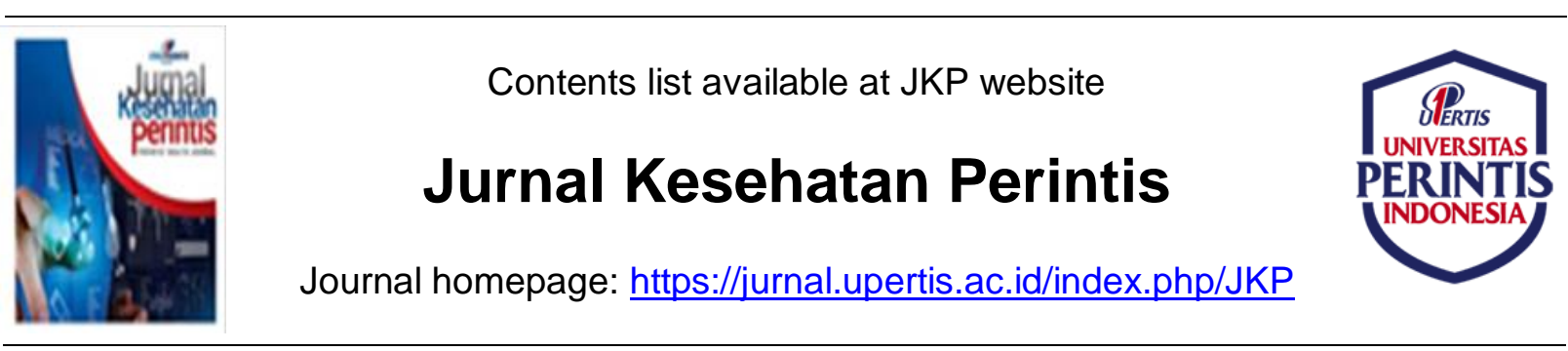

\title{
Kecemasan pada Masa Pandemi Covid-19 Meningkatkan Tekanan Darah Lansia
}

\author{
Desi Evitasari, Merlly Amalia, Yeni Meriyani Pikna \\ STIKes YPIB Majalengka, Jawa Barat, Indonesia
}

Article Information :

Submission: Nov 2, 2021; Revised:Nov 21, 2021; Accepted:Dec 30, 2021; Available online: Dec 31,2021

*Corresponding author : drindro@staff.ubaya.ac.id

\begin{abstract}
ABSTRAK
Pandemi Covid-19 dapat menjadi stressor bagi lansia sehingga menimbulkan kecemasan. Kecemasan dapat meningkatkan tekanan darah pada lansia sehingga menimbulkan kejadian hipertensi. Kejadian hipertensi pada lansia di UPTD Puskesmas DTP Argapura Kabupaten Majalengka tahun 2019-2020 mengalami kenaikan yaitu dari 25,7\% menjadi $28,4 \%$ atau naik sebesar 2,7\%. Penelitan ini bertujuan untuk mengidentifikasi pengaruh kecemasan pada masa pandemi Covid-19 terhadap peningkatan tekanan darah lansia di Wilayah Kerja UPTD Puskesmas DTP Argapura Kabupaten Majalengka. Penelitian ini merupakan penelitian kuantitatif dengan pendekatan cross sectional. Subjek pada penelitian ini yaitu lansia di wilayah kerja UPTD Puskesmas DTP Argapura Kabupaten Majalengka sebanyak 92 orang pada bulan Mei-Juni 2021. Pengumpulan datanya untuk kecemasan menggunakan instrumen Zung Self Anxiety Scale (ZSAS), sedangkan untuk mengukur tekanan darah menggunakan Sphygmomanometer dan stetoskop. Analsis data menggunakan uji chi square. Kurang dari setengah $(27,2 \%)$ lansia pada masa pandemi Covid-19 mengalami cemas sedang dan lebih dari setengah $(54,3 \%)$ lansia mengalami hipertensi stadium 1. Terdapat pengaruh kecemasan lansia pada masa pandemi Covid-19 dengan peningkatan tekanan darah pada lansia di wilayah kerja UPTD Puskesmas DTP Argapura Kabupaten Majalengka dengan $\rho$ value $=0,000$. Kecemasan pada masa pandemi Covid-19 terbukti meningkatkan tekanan darah pada lansia.
\end{abstract}

Kata kunci : covid-19, hipertensi, kecemasan, lansia

\section{ABSTRACT}

The Covid-19 pandemic can be a stressor for the elderly, causing anxiety. Anxiety can increase blood pressure in the elderly, causing hypertension. The incidence of hypertension in the elderly at the UPTD Puskesmas DTP Argapura Majalengka Regency in 2019-2020 has increased from $25.7 \%$ to $28.4 \%$ or an increase of $2.7 \%$. This study aims to identify the effect of anxiety during the Covid-19 pandemic on increasing the blood pressure of the elderly in the UPTD Work Area of the Argapura DTP Health Center, Majalengka Regency. This research is a quantitative research with a cross sectional approach. The subjects in this study were the elderly in the working area of the UPTD Puskesmas DTP Argapura Majalengka Regency as many as 92 people in May-June 2021. The data collection for anxiety used the Zung Self Anxiety Scale (ZSAS) instrument, while to measure blood 
pressure using a sphygmomanometer and a stethoscope. Analysis used chi square test. Less than half (27.2\%) of the elderly during the Covid-19 pandemic experienced moderate anxiety and more than half (54.3\%) of the elderly experienced stage 1 hypertension. elderly in the working area of UPTD Puskesmas DTP Argapura Majalengka Regency with $\rho$ value $=$ 0.000. Anxiety during the Covid-19 pandemic has been shown to be effective in increasing blood pressure in the elderly.

Keywords: covid-19, hypertension, anxiety, elderly

\section{PENDAHULUAN}

Kesehatan seseorang merupakan kondisi sejahtera yang meliputi aspek jiwa, raga dan sosial dari setiap individu produktif yang mempunyai nilai ekonomis. Maka dari itu, kesehatan termasuk dasar dari diakuinya derajat kemanusiaan seseorang. Tanpa kesehatan, seseorang menjadi tidak sederajat dalam kondisi tertentu. Namun, masalah kesehatan saat ini sedang diuji dengan adanya pandemi Covid-19 (Ardinata, 2020). Sejak dinyatakan pandemi, virus ini mendapat beragam respons yang beragam dari masyarakat. Sebagian mulai berhati-hati dan menerapkan pola hidup sehat, dan tidak sedikit yang terkesan meremehkan. Namun bagi orang lanjut usia (lansia) wabah pandemi ini menjadi suatu ancaman yang serius, karena lansia termasuk kelompok risiko tinggi tertular Covid-19 (Susilo \& Rumende, 2020).

Pertambahan usia seseorang terutama menginjak usia lanjut dapat menyebabkan tubuh mengalami penurunan yang diakibatkan karena adanya proses penuaan, fungsi-fungsi organ serta gerak dapat mengalami penurunan, diikuti dengan menurunnya imunitas sebagai pelindung tubuh, hingga tidak bekerja seperti waktu masih muda (Purwaningsih, 2021). Kondisi yang demikian itu, menyebabkan lansia rentan mengalami berbagai penyakit, termasuk penyakit Covid-19 yang disebabkan oleh virus Sars-Cov-2. Sistem imun yang sudah melemah ditambah adanya penyakit kronis dapat meningkatkan risiko Covid-19 pada lansia (Widiharti et al., 2020).

Pada masa pandemi ini lansia merupakan salah satu kelompok yang rentan mengalami kematian jika terserang virus Covid-19. Kematian pada kasus Covid-19 pada lansia dikarenakan salah satunya karena ada penyakit penyerta. Salah satu penyakit penyerta yang banyak dialami lansia adalah pada sistem kardiovaskuler. Penyakit sistem kardiosvaskuler yang mematikan dan menjadi masalah utama pada lansia di negara-negara maju dan berkembang adalah penyakit hipertensi (Fridalni et al., 2020). Hipertensi atau penyakit yang ditandai adanya kenaikan atau penambahan tekanan darah merupakan gangguan pada sistem peredaran darah yang ditandai kenaikan tekanan darah di atas batas normal, yaitu lebih dari 140 / 90 mmHg (Kumala et al., 2021).

Prevalensi hipertensi meningkat pada kelompok lansia. Batasan lansia menurut World Health Organization (WHO), lansia adalah yang berusia lebih dari 60 tahun ke atas. Prevalensi hipertensi (2019) di dunia yaitu $15-20 \%$ dari jumlah penduduk. Adapun di beberapa negara seperti di Korea $14.1 \%$, Hongkong 9.5\%, Singapura $16.2 \%$, dan Filipina $17.2 \%$. Sedangkan prevalensi di Indonesia tahun 2019, untuk kelompok umur 45-54 tahun (35,6\%), 55-64 tahun $(45,9 \%)$, umur $65-74$ tahun $(57,6 \%)$, dan umur 75 tahun lebih adalah $63,8 \%$ (Arifin et al., 2021).

Prevelensi hipertensi di Provinsi Jawa Barat tahun 2019 untuk lansia adalah $57,5 \%$, prevalensi ini mengalami kenaikan jika dibanding tahun sebelumnya yaitu pada tahun $2018(54,2 \%)$ (Dinas Kesehatan Propinsi Jawa Barat, 2020). Adapun jumlah lansia yang mengalami hipertensi paling banyak di Kabupaten Majalengka adalah Puskesmas Argapura sebanyak 291 kasus $(25,7 \%)$ dari jumlah lansia sebanyak 1.132 lansia (Dinas Kesehatan Kabupaten Majalengka, 2020).

Peningkatan tekanan darah pada masa pandemi ini dapat dikarenakan faktor rasa takut dan khawatir atau kecemasan. Lansia yang mengalami kecemasan menyebabkan terjadinya peningkatan tekanan darah. Pada saat cemas, hormon adrenalin akan meningkat yang mengakibatkan jantung 
memompa darah lebih cepat, sehingga tekanan darah meningkat (Fridalni et al., 2020). Sehingga Covid-19 menjadi ancaman atau stressor terhadap kecemasan lansia pada masa pandemi sehingga lansia merasakan kekhawatiran dan ketakutan. Kecemasan yang berlebih menyebabkan lansia tidak dapat mengontrol diri dan justru memperburuk kondisi fisik maupun psikologisnya. Kondisi ini akan mempermudah virus Covid-19 menyerang dan menjadi penyebab kematian paling tinggi pada lansia terutama lansia yang mempunyai riwayat penyakit penyerta seperti hipertensi (Arifin et al., 2021).

Umumnya lansia sering mengalami kecemasan tentang rasa takutnya terhadap kematian, kehilangan keluarga atau teman karib, kedudukan sosial, pekerjaan, atau masalah dalam rumah tangga (Aritonang et al., 2021). Kekhawatiran akan timbulnya masalah baru pada hipertensi khususnya di masa pandemi Covid-19 akan menyebabkan gangguan mental emosional yang banyak ditunjukkan dengan gangguan kecemasan. Gangguan kecemasan yang banyak dialami lansia adalah kecemasan menyeluruh. Kecemasan dapat ditimbulkan dari peristiwa sehari-hari yang dapat dialami manusia dan dapat juga dialami oleh siapapun (Aspiani, 2016).

Hasil penelitian (Rismawati \& Novitayanti, 2020) menunjukkan bahwa ada hubungan tingkat kecemasan terhadap peningkatan tekanan darah pada kelompok lansia. Juga penelitian (Agustin et al., 2020) menunjukkan bahwa korelasi antara tingkat kecemasan dengan hipertensi termasuk kategori derajat asosiasi kuat. Perbedaan penelitian ini dengan penelitian sebelumnya yaitu pada penelitian ini stressor kecemasan lansia dikarenakan adanya pandemi Coviid-19.

Hasil studi pendahuluan terhadap 10 lansia di Wilayah Kerja UPTD Puskesmas DTP Argapura Kabupaten Majalengka, didapatkan sebanyak 7 lansia mengalami tekanan darah di atas batas normal dan 3 lansia masih dalam batas normal. Dari 10 lansia tersebut juga diketahui bahwa sebanyak 8 lansia merasakan cemas akan wabah Covid-19 dan takut dirinya menderita penyakit Covid-19 karena faktor usianya yang rentan dan mudah terserang penyakit, sedangkan 2 lansia tidak merasa khawatir karena selalu melakukan pengontrolan secara teratur dengan selalu menjaga protokol kesehatan. Penelitian ini bertujuan untuk mengidentifikasi pengaruh kecemasan masa pandemi Covid-19 dengan peningkatan tekanan darah pada lansia.

\section{METODE PENELITIAN}

Penelitian ini menggunakan jenis penelitian kuantitatif dengan pendekatan cross sectional. Sampelnya yaitu lansia di wilayah kerja UPTD Puskesmas DTP Argapura Kabupaten Majalengka sebanyak 92 orang pada bulan Mei-Juni 2021. Pengumpulan data pada penelitian ini menggunakan kuesioner kecemasan Zung Self Anxiety Scale (ZSAS). Instrumen ZSAS merupakan salah satu instrumen kecemasan yang sudah baku sebanyak 20 item pertanyaan terbuka (Nursalam, 2016). Sedangkan untuk mengukur tekanan darah menggunakan Sphygmomanometer, stetoskop Analisis data menggunakan uji chi square menggunakan komputerisasi.

\section{HASIL DAN PEMBAHASAN}

Berdasarkan hasil penelitian tabel 1 menunjukkan bahwa lebih banyak lansia yang tidak cemas menghadapi pandemic covid 19, namun terdapat $27,2 \%$ lansia yang mengalami cemas sedang dan 34,8\% cemas ringan. Lebih banyak lansia yang mengalami stadium 1 sebesar $54,3 \%$, semantara yang pre hipertensi sebanyak $45,7 \%$. Tabel 2, menunjukkan bahwa lansia yang mengalami hipertensi stadium I lebih

Tabel 1. Tingkat Kecemasan dan Tekanan Darah Lansia pada Masa Pandemi Covid-19

\begin{tabular}{lcc}
\hline \multicolumn{1}{c}{ Variabel } & f & $\%$ \\
\hline Kecemasan & & \\
Cemas sedang & 25 & 27,0 \\
Cemas ringan & 32 & 34,0 \\
Tidak cemas & 35 & 38,0 \\
Tekanan Darah & & \\
Stadium 1 & 50 & 54,3 \\
Pre hipertensi & 42 & 45,7 \\
\hline
\end{tabular}


Tabel 2. Kecemasan pada Masa Pandemi Covid-19 terhadap Tekanan Darah

\begin{tabular}{|c|c|c|c|c|c|c|c|}
\hline \multirow{3}{*}{ Kategori } & \multicolumn{4}{|c|}{ Tekanan Darah } & & & \multirow[t]{3}{*}{ p Value } \\
\hline & \multicolumn{2}{|c|}{$\begin{array}{l}\text { Hipertensi } \\
\text { Stadium I }\end{array}$} & \multicolumn{2}{|c|}{ Pre Hipertensi } & \multicolumn{2}{|c|}{ Total } & \\
\hline & $\mathbf{n}$ & $\%$ & $n$ & $\%$ & $\mathbf{N}$ & $\%$ & \\
\hline Cemas sedang & 25 & 88,0 & 3 & 12,0 & 25 & 100 & 0,000 \\
\hline Cemas ringan & 16 & 50,0 & 16 & 50,0 & 32 & 100 & \\
\hline Tidak cemas & 12 & 34,3 & 23 & 65,7 & 35 & 100 & \\
\hline Jumlah & 50 & 54,3 & 42 & 45,7 & 92 & 100 & \\
\hline
\end{tabular}

banyak yang mengalami cemas sedang $(88,0 \%)$ dibanding lansia yang mengalami pre hipertensi (12,0\%). Uji statistik dengan uji chi square pada $\alpha=0,05$ diperoleh $\rho$ value $=0,000$, sehingga $p$ value $<\alpha(0,05)$. sehingga hipotesis nol ditolak yang artinya bahwa terdapat pengaruh kecemasan pada masa pandemi Covid-19 lansia terhadap peningkatan tekanan darah lansia. Adanya pengaruh hal ini dapat dikarenakan lansia yang cemas maka dirinya tidak dapat mengontrol faktor risiko penyebab hipertensi seperti pola makan, istirahat, aktivitas fisik akibatnya tekanan darah pada lansia tidak terkontrol dan mengakibatkan hipertensi semakin tinggi.

Hasil penelitian ini sejalan dengan hasil penelitian (Rismawati \& Novitayanti, 2020) menunjukkan bahwa terdapat hubungan yang signifikan antara tingkat kecemasan dengan peningkatan tekanan darah pada lansia dengan nilai $p=0,000$. Juga sejalan dengan (Agustin et al., 2020) menunjukkan bahwa korelasi antara tingkat kecemasan dengan hipertensi termasuk kategori derajat asosiasi kuat dengan nilai $p$ $=0,001$.

Kondisi pandemi dapat menjadi stressor terhadap munculnya kecemasan pada lansia dan meningkatkan kejadian hipertensi pada lansia. Peningkatan tekanan darah pada masa pandemi ini dapat dikarenakan faktor rasa takut dan khawatir atau kecemasan. Lansia yang mengalami kecemasan menyebabkan terjadinya peningkatan tekanan darah. Pada saat cemas, hormon adrenalin akan meningkat yang mengakibatkan jantung memompa darah lebih cepat, sehingga tekanan darah meningkat (Tobing \& Wulandari, 2021).
Maka dari itu lansia perlu memperhatikan protokol kesehatan Covid19 saat keluar rumah atau sedang memeriksaan kesehatan, dan juga aktif berkonsultasi dengan petugas kesehatan. Bagi petugas kesehatan perlu meningkatkan penyuluhan tentang hipertensi pada lansia di masa pandemi Covid-19 serta memberikan motivasi pada lansia untuk selalu menerapkan protokol kesehatan Covid-19, serta memberikan pelatihan terapi relaksasi pada lansia untuk mengatasi kecemasan.

\section{KESIMPULAN}

Kesimpulan dari penelitian ini adalah lebih banyak lansia yang tidak cemas menghadapi pandemic covid 19, namun terdapat $27,2 \%$ lansia yang mengalami cemas sedang dan $34,8 \%$ cemas ringan. Lebih banyak lansia yang mengalami stadium 1 sebesar $54,3 \%$, semantara yang pre hipertensi sebanyak $45,7 \%$. Terdapat pengaruh kecemasan lansia pada masa pandemi Covid-19 terhadap peningkatan tekanan darah lansia di wilayah kerja UPTD Puskesmas DTP Argapura Kabupaten Majalengka dengan $\rho$ value $=0,000$.

\section{REFERENSI}

Agustin, N., Liliek, P., \& Permatasari, L. I. (2020). Hubungan Tingkat Kecemasan dengan Kejadian Hipertensi pada Ibu Hamil di Wilayah Kerja Puskesmas Susukan Kecamatan Susukan Kabupaten Cirebon Tahun 2019. Jurnal IImu Kesehatan UMC, 9(2).

Ardinata, M. (2020). Tanggung Jawab Negara Terhadap Jaminan Kesehatan Dalam Perspektif Hak Asasi Manusia. Jurnal HAM, 319-333.

Arifin, Z., Istianah, Hapipah, Ilham, 
Supriyadi, \& Ariyanti, M. (2021). Edukasi Tentang Hipertensi Pada Lansia Di Masa Pandemi Covid-19 Di Desa Ubung Lombok Tengah. Abdimas Madani, 3(1).

Aritonang, J., Sirait, A., \& Lumbantoruan, M. (2021). Tingkat Kecemasan Kelompok Lanjut Usia Di Situasi Pandemi Covid-19. In Jurnal Kesehatan Delima Pelamonia (Vol. 5, Issue 1).

Aspiani, R. Y. (2016). Buku Ajar Asuhan Keperawatan Klien Gangguan Kardiovaskular. In Buku Kedokteran EGC. Buku Kedokteran ECG.

Dinas Kesehatan Kabupaten Majalengka. (2020). Profil Kesehatan Kabupaten Majalengka Tahun 2019. Dinas Kesehatan Kabupaten Majalengka.

Fridalni, N., Minropa STIKes Mercubaktijaya Padang, A., Gadang, S., Nanggalo, K., Padang, K., \& Barat, S. (2020). Faktor yang Berhubungan dengan Tingkat Kecemasan Lansia pada Masa Pandemi Covid 19. Jurnal Keperawatan, 12(4), 1079-1088.

Kumala, M., Yanti, D., Silaban, L., \& Santoso, H. (2021). Edukasi Pola Makan Sehat dalam Upaya Pengendalian Hipertensi di Masa Pandemi COVID-19. Jurnal Bakti Masyarakat Indonesia, 4(1).

Kurnia, A. (2020). Self Management Hypertension. In Nuha Medika. Nuha
Medika.

Nursalam. (2016). Metode Penelitian IImu Keperawatan. In Journal of Chemical Information and Modeling (Vol. 53, Issue 9).

Purwaningsih, E. (2021). Covid-19 Transmission Risk Management for Hypertensive Patients in Indonesia. Insights in Public Health Journal.

Rismawati, \& Novitayanti, E. (2020). Hubungan Kecemasan dengan Tekanan Darah pada Lansia. Stethoscope, 1(1).

Susilo, A., \& Rumende, C. M. (2020). Coronavirus Disease 2019: Tinjauan Literatur Terkini Coronavirus Disease 2019: Review of Current Literatures. Jurnal Penyakit Dalam Indonesia, 7(1), 45-67.

Tobing, C. P. R. L., \& Wulandari, I. S. M. (2021). Tingkat Kecemasan Bagi Lansia Yang Memiliki Penyakit Penyerta Ditengah Situasi Pandemik Covid-19 Di Kecamatan Parongpong, Bandung Barat. Community of Publishing In Nursing (COPING), pISSN 2303-1298, e-ISSN 2715-1980, 8(April 2021).

Widiharti, W., widiyawati, W., \& Fitrianur, W. L. (2020). Faktor-Faktor yang Berhubungan dengan Tekanan Darah pada Masa Pandemi Covid-19. Journal Of Health Science (Jurnal IImu Kesehatan), 5(2), 61-67. 